\title{
PEMBELAJARAN PENJUMLAHAN PECAHAN PENYEBUT BERBEDA MELALUI PENGGUNAAN MEDIA GAMBAR PADA SISWA KELAS V SD NEGERI 1 KUMAI HILIR TAHUN AJARAN 2018/2019
}

\author{
YUCE, S.Pd SD \\ NIP. 196710041987122002
}

SD Negeri 1 kunmai Hilir

\begin{abstract}
Abstrak
Banyak orang cerdas dan berpendidikan tinggi tetapi belum mampu menjadi seorang yang jujur. Lebih mudah menemukan manusia yang pintar daripada yang jujur sampai-sampai ada sebuah quotes yang mengatakan kalau negara ini sedang tidak kekurangan orang berpendidikan namun orang jujur. Matematika merupakan alat untuk memberikan cara berpikir, menyusun pemikiran yang jelas, tepat, dan teliti. Hudojo (2005) menyatakan, matematika sebagai suatu obyek abstrak, tentu saja sangat sulit dapat dicerna anak-anak Sekolah Dasar (SD) yang mereka oleh Piaget, diklasifikasikan masih dalam tahap operasi konkret. Siswa SD belum mampu untuk berpikir formal maka dalam pembelajaran matematika sangat diharapkan bagi para pendidik mengaitkan proses belajar mengajar di SD dengan benda konkret.

Hasilya: 1) Kelas dibagi menjadi beberapa kelompok kecil (5 siswa) untuk memudahkan dalam pengawasan. (2) Guru menunjuk ketua dan sekretaris untuk mengkondisikan anggota kelompoknya masing-masing, yaitu mencatat para anggotanya . (3) Guru menjelaskan pelajaran menggunakan media gambar untuk lebih mudah diingat oleh siswa yang kemudian dipraktikkan oleh masingmasing kelompok dengan gambar masih dipasang di depan kelas. (4) Masing-masing kelompok melaksanakan praktikkan tanpa gambar. (5) Guru mengamati pelaksanaan praktik siswa pada siklus I maupun siklus II. (6) Guru memastikan siswa melafalkan Pembelajaran Penjumlahan Pecahan Penyebut Berbeda dalam kondisi yang kondusif jadi siswa bisa fokus terhadap kegiatan pembelajaran. (7) Setelah selesai setiap kelompok ditanya dimana kesulitannya dalam Pembelajaran Penjumlahan Pecahan Penyebut Berbeda, kemudian ketua kelompok membimbing anggotanya yang masih kesulitan memecahkan masalah dimana yang masih dianggap sulit.

Pembelajaran matematika pada materi Pembelajaran Penjumlahan Pecahan Penyebut Berbeda dengan media gambar dapat meningkatkan prestasi belajar siswa Kelas V SD Negeri 1 Kumai Hilir Semester I tahun ajaran 2018/2019. Ini terbukti pada penelitian pra siklus rata-rata hasil belajar masih 63,33. Mengalami peningkatan pada siklus I menjadi 69,71 dan meningkat lagi pada penelitian tindakan siklus II sehingga dapat mencapai nilai diatas kriteria minimum 70 yaitu dengan nilai ratarata 77,08 .
\end{abstract}

Kata Kunci:

\section{PENDAHULUAN}

Heruman (2008) menyatakan dalam pembelajaran matematika $\mathrm{SD}$, diharapkan terjadi reinvention (penemuan kembali). Penemuan kembali adalah menemukan suatu cara penyelesaian secara informal dalam pembelajaran di kelas. Selanjut Heruman menambahkan bahwa dalam pembelajaran matematika harus terdapat keterkaitan antara pengalaman belajar siswa sebelumnya dengan konsep yang akan diajarkan.

Siswa Sekolah Dasar (SD) berada pada umur yang berkisar antara usia 7 hingga 12 tahun, pada tahap ini siswa masih berpikir pada fase operasional konkret. Kemampuan yang tampak dalam fase ini adalah kemampuan dalam proses berpikir untuk mengoperasikan kaidah-kaidah logika, 
meskipun masih terikat dengan objek yang bersifat konkret (Heruman, 2008). Siswa SD masih terikat dengan objek yang ditangkap dengan pancaindra, sehingga sangat diharapkan dalam pembelajaran matematika yang bersifat abstrak, peserta didik lebih banyak menggunakan media sebagai alat bantu, dan penggunaan alat peraga. Karena dengan penggunaan alat peraga dapat memperjelas apa yang disampaikan oleh guru, sehingga siswa lebih cepat memahaminya. Pembelajaran matematika di SD tidak terlepas dari dua hal yaitu hakikat matematika itu sendiri dan hakikat dari anak didik di SD.

Oleh karenananya, peneliti yang sekaligus guru Matematika hendak mengajarkan Penjumlahan Pecahan Penyebut Berbeda kepada siswa melalui media gambar. Media gambar ialah suatu media visual yang hanya dapat dilihat saja, akan tetapi tidak mengandung unsur suara atau audio. Atau definisi Media Gambar yang lainnya ialah segala sesuatu yang dapat diwujudkan secara visual kedalam bentuk 2 ( dua ) dimensi sebagai curahan ataupun pemikiran yang bermacam-macam misalnya seperti: potret, slide, lukisan, film, strip, opaque proyektor dan sebagainya.

Dari latar belakang itulah maka penelitian ini mengambil judul: "Pembelajaran Penjumlahan Pecahan Penyebut Berbeda Melalui Penggunaan Media Gambar Pada Siswa Kelas V SD Negeri 1 Kumai Hilir Tahun Ajaran 2018/2019"

\section{TINJAUAN PUSTAKA}

\section{B) Media Gambar}

\section{a. Pengertian Media Gambar}

Kata media berasal dari bahasa Latin medium yang secara harfiah berarti "tengah", "perantara", atau "pengantar". Dalam bahasa Arab, media adalah perantara (وَسَايِل) atau pengantar pesan dari pengirim kepada penerima pesan. Gerlach dan Ely (1971) mengatakan bahwa media apabila dipahami secara garis besar adalah manusia, materi atau kejadian yang menyambung kondisi yang membuat siswa mampu memperoleh pengetahuan, keterampilan atau sikap. Dalam hal ini, guru, buku teks, dan lingkungan sekolah merupakan media. Secara khusus, pengertian media dalam proses belajar mengajar cenderung diartikan sebagai alat-alat grafis, photografis atau elektronis untuk menangkap, memproses, dan menyususn kembali informasi visual dan verbal.

\section{b. Jenis-jenis Media Gambar/Foto}

Ada beberapa jenis media gambar/foto, antara lain:

1) Gambar/foto dokumentasi, yaitu gambar yang mempunyai nilai sejarah bagi individu maupun masyarakat

2) Gambar/foro aktual, yaitu gambar yang menjelaskan sesuatu kejadian yang meliputi berbagai aspek kehidupan misalnya gempa, topan, dan sebagainya

3) Gambar/foto pemandangan, yaitu gambar yang melukiskan pemandangan sesuatu daerah atau lokasi

4) Gambar/foto iklan atau reklame, yaitu gambar yang digunakan untuk mempengaruhi orang atau masyarakat konsumen.

5) Gambar/foto simbolis, yaitu gambar yang menggunakan bentuk simbol atau tanda yang menggunakan message (pesan) tertentu dan dpat mengungkapkan kehidupan manusia yang mendalam serta gagasan- gagasan atau ide-ide anak didik.

\section{c. Manfaat media gambar}

Ada beberapa manfaat tentang media gambar bagi guru maupun bagi para siswa, yaitu antara lain:

1) Memudahkan pengertian ketika anakanak sedang mendengarkan

2) Dapat melafalkan dengan baik arti dari kosa kata

3) Dapat membaca dengan benar

4) Tersedianya suatu topik kata

5) Memudahkan jalan komunikasi antara guru dan murid

d. Fungsi Media Gambar

Pemanfaatan media pembelajaran ada dalam komponen metode mengajar sebagai salah satu upaya untuk mempertinggi proses interaksi guru-siswa dan interaksi siswa dengan lingkungan belajarnya. Oleh sebab itu fungsi utama dari media pembelajaran adalah 
sebagai alat bantu mengajar yang dipergunakan guru.

C) Penerapan Pembelajaran dengan Media Gambar dapat Meningkatkan Pembelajaran Penjumlahan Pecahan Penyebut Berbeda

Melalui media gambar ini, yang diterapkan pada pembelajaran mata pelajaran Matematika pada pokok bahasan Pembelajaran Penjumlahan Pecahan Penyebut Berbeda, diharap bisa membantu guru dalam melaksanakan pembelajaran yang dilakukan di Kelas V SD Negeri 1 Kumai Hilir dan juga bisa membantu siswa dalam memahami materi yang disampaikan. Dengan demikian pembelajaran bisa berjalan dengan lancar dan akhirnya bisa menghasilkan hasil yang maksimal sesuai dengan harapan.

\section{METODE PENELITIAN}

\section{A.Jenis Penelitian}

Jenis penelitian yang digunakan dalam penelitian ini adalah Penelitian Tindakan Kelas (Classroom Action Research). Penelitian tindakan merupakan suatu proses yang memberikan kepercayaan pada pengembangan kekuatan berpikir reflektif, diskusi, penentuan keputusan dan tindakan oleh orang- orang biasa, berpartisipasi penelitian kolektif mengatasi kesulitankesulitan yang mereka hadapi kegiatannya.

Mengutip definisi yang dikemukakan oleh Stephen Kemmis seperti dikutip dalam D. Hopkins dalam bukunya yang berjudul A Teacher's Guide To Classroom Reaserch, Bristol, PA. Open University Press, 1993, halaman 44 dapat dijelaskan pengertian PTK adalah sebagai suatu bentuk kajian yang bersifat reflektif oleh pelaku tindakan, yang dilakukan untuk meningkatkan kemantapan rasional dari tindakan-tindakan mereka dalam melaksanakan tugas, memperdalam pemahaman terhadap tindakan-tindakan yang dilakukan itu, memperbaiki kondisi di mana praktek-praktek pembelajaran tersebut dilakukan serta dilakukan secara kolaboratif.

\begin{tabular}{|l|l|l|l|l|l|}
\hline 3 & Persiapan & & & & \\
\hline
\end{tabular}

Penelitian ini menurut Kurt Lewin menggambarkan penelitian tindakan sebagai suatu proses siklikal spiral yang meliputi beberapa langkah yaitu perencanaan, pelaksanaan, pengamatan dan refleksi.

\section{B.Tempat dan Waktu Penelitian}

Penelitian ini dilakukan di SD Negeri 1 Kumai Hilir. Penelitian ini berlangsung selama satu bulan (4 minggu). Pada minggu pertama digunakan untuk kegiatan persiapan, yaitu dengan melakukan penentuan siswa yang diteliti, mengkondisikan tempat untuk praktik, dan persiapan administrasi, dan juga digunakan untuk kegiatan pembelajaran siswa tentang Pembelajaran Penjumlahan Pecahan Penyebut Berbeda (siklus I), yaitu melaksanakan pembelajaran oleh guru di kelas dengan menggunakan metode ceramah kemudian dilengkapi dengan menggunakan gambar Pembelajaran Penjumlahan Pecahan Penyebut Berbeda, pertama menggunakan gambar secara satu per satu Pembelajaran Penjumlahan Pecahan Penyebut Berbeda.

Minggu ketiga pelaksanaan pembelajaran siklus II, yaitu guru melakukan proses pembelajaran dengan materi Pembelajaran Penjumlahan Pecahan Penyebut Berbeda. Tetapi lebih meningkatkan pada penggunaan media gambarnya. Minggu keempat evaluasi untuk siklus II. Evaluasi berupa tes materi Pembelajaran Penjumlahan Pecahan Penyebut Berbeda dimulai dari bersama-sama kemudian tes secara individu. Pada pelaksanaannya nanti akan direfleksi pada setiap siklus berjalan. Untuk lebih detailnya dapat dilihat pada jadwal penelitian sebagai berikut:

\section{Tabel 1}

Jadwal Kegiatan Penelitian Tindakan Kelas

\begin{tabular}{|c|l|c|c|c|c|}
\hline No & Rencana Kegiatan & \multicolumn{3}{|c|}{$\begin{array}{l}\text { Waktu } \\
\text { (Minggu) } \\
\text { ke- }\end{array}$} \\
\cline { 3 - 6 } & & 1 & 2 & 3 & 4 \\
\hline 1 & $\begin{array}{l}\text { Kondisi awal } \\
\text { (observasi awal) }\end{array}$ & $\sqrt{ }$ & & & \\
\hline 2 & $\begin{array}{l}\text { Penyerahan } \\
\text { proposal }\end{array}$ & $\sqrt{ }$ & & & \\
\hline & Menyusun & $\sqrt{ }$ & & & \\
\hline
\end{tabular}




\begin{tabular}{|c|c|c|c|c|}
\hline & $\begin{array}{l}\quad \text { Konsep } \\
\text { Pelaksanaan } \\
\text { pembelajaran }\end{array}$ & & & \\
\hline & $\begin{array}{l}\text { Menyusun } \\
\text { instrumen } \\
\text { penelitian. }\end{array}$ & $\sqrt{ }$ & & \\
\hline & $\begin{array}{l}\text { Menyepakati } \\
\text { jadwal dan tugas } \\
\text { penelitian }\end{array}$ & $\sqrt{ }$ & & \\
\hline & $\begin{array}{l}\text { Diskusi Konsep } \\
\text { pelaksanaan } \\
\text { penelitian. }\end{array}$ & $\sqrt{ }$ & & \\
\hline \multirow[t]{4}{*}{4} & $\begin{array}{l}\text { Pelaksanaan } \\
\text { Mempersiapkan } \\
\text { bahan } \\
\text { pembelajaran. }\end{array}$ & & $\sqrt{ }$ & \\
\hline & $\begin{array}{l}\text { Pelaksanaan } \\
\text { pembelajaran }\end{array}$ & & $\sqrt{ }$ & \\
\hline & $\begin{array}{l}\text { Pembelajaran } \\
\text { dengan media } \\
\text { gambar }\end{array}$ & & $\sqrt{ }$ & \\
\hline & $\begin{array}{l}\text { Melakukaan } \\
\text { praktik } \\
\text { Pembelajaran } \\
\text { Penjumlahan } \\
\text { Pecahan Penyebut } \\
\text { Berbeda dengan } \\
\text { bersama-sama }\end{array}$ & & $\sqrt{ }$ & \\
\hline \multirow[t]{3}{*}{5} & Observasi & & $\sqrt{ }$ & \\
\hline & $\begin{array}{l}\text { Evaluasi siklus I } \\
\text { dengan praktik } \\
\text { Pembelajaran } \\
\text { Penjumlahan } \\
\text { Pecahan Penyebut } \\
\text { Berbeda secara } \\
\text { individu }\end{array}$ & & & \\
\hline & $\begin{array}{l}\text { Melakukan } \\
\text { penilaian praktik } \\
\text { Pembelajaran } \\
\text { Penjumlahan } \\
\text { Pecahan Penyebut } \\
\text { Berbeda secara } \\
\text { kelompok lima } \\
\text { siswa }\end{array}$ & & $\sqrt{ }$ & \\
\hline 6 & $\begin{array}{l}\text { Refleksi } \\
\text { Mencatat semua } \\
\text { aktifitas siswa, } \\
\text { lebih- lebih } \\
\text { terhadap } \\
\text { kekurangan atau }\end{array}$ & & $\sqrt{ }$ & \\
\hline
\end{tabular}

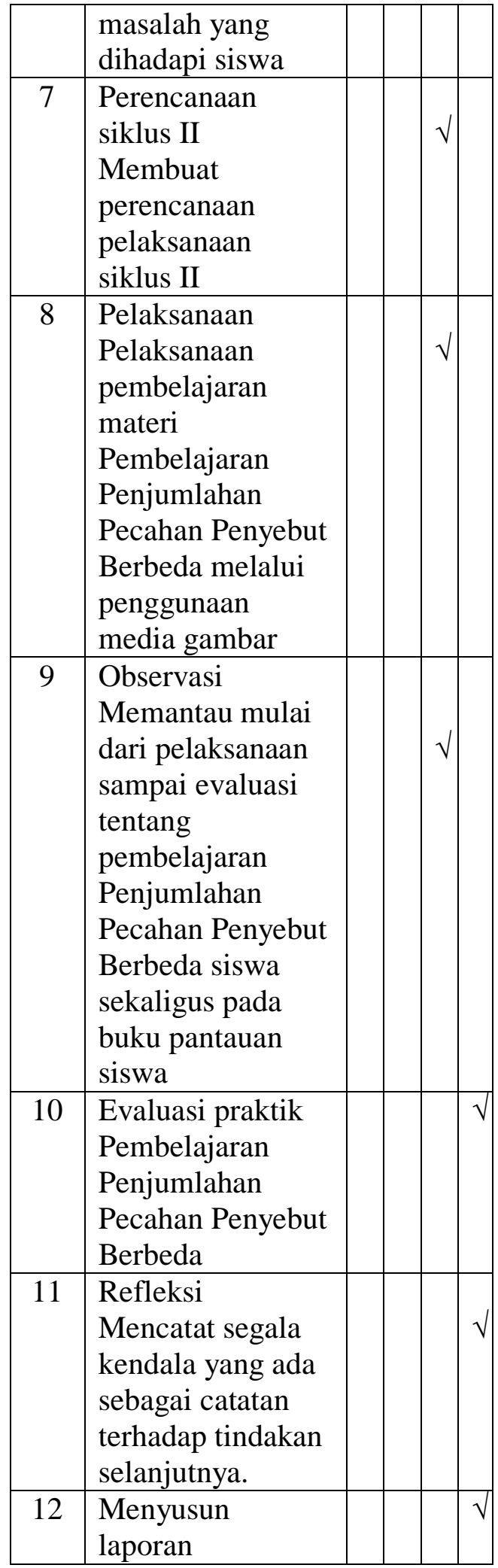

\section{C.Pelaksanaan dan Peneliti}

Dalam Pelaksanaan Class Action Research (CAR), peneliti adalah guru dalam pelaksanaan penelitian, peneliti adalah guru Kelas V SD Negeri 1 Kumai Hilir tahun ajaran 2018/2019 yaitu Yuce, S.Pd SD 


\section{Rancangan Penelitian}

Dalam langkah-langkah PTK untuk setiap siklusnya terdiri dari 4 langkah yaitu yang terdiri dari perencanaan tindakan (planing), pelaksanaan tindakan (acting), observasi (observing), refleksi (reflecting). berikut :

Secara rinci dapat digambarkan sebagai

1.,Pra Siklus

a.,Perencanaan Tindakan

1) Guru menyampaikan kepada siswa bahwa nantinya beberapa inggu kedepan untuk materi Pembelajaran Penjumlahan Pecahan Penyebut Berbeda.

2) Guru menentukan materi yaitu tentang Pembelajaran Penjumlahan Pecahan Penyebut Berbeda

3) Guru menyiapkan administrasi pembelajaran pada materi Pembelajaran Penjumlahan Pecahan Penyebut Berbeda yaitu membuat RPP

b. Pelaksanaan Tindakan

1) Guru membuka pelajaran dengan berdoa bersama

2) Guru mengabsensi siswa

3) Guru meelakukan apersepsi sebelum memulai pembelajaran, yaitu yang berisi pertanyaan-pertanyaan tentang pelajaran yang lalu dan juga berisi motivasi tentang tujuan dan manfaatnya ketika mempelajari materi Pembelajaran Penjumlahan Pecahan Penyebut Berbeda.

4) Guru memulai masuk proses pembelajaran dengan menerangkan materi pembelajaran yaitu tentang Pembelajaran Penjumlahan Pecahan Penyebut Berbeda.

5) Guru menjelaskan materi Pembelajaran Penjumlahan Pecahan Penyebut Berbeda hanya menggunakan metode konvensional saja (ceramah)

6) Sebelum menutup pembelajaran guru memberi kesempatan kepada siswa untuk bertanya jika ada yang masih belum jelas.

7) Guru menyimpulkan pembelajaran

c. Observasi

1) Guru memantau proses pembelajaran

2) Guru mengamati aktifitas siswa

3) Guru mengamati keselarasan perencanaan terhadap pelaksanaan
4) Guru mengadakan evaluasi pembelajaran

d. Refleksi

1) Guru mencatat segala hambatan selama melakukan pembelajaran

2) Guru menganalisa faktor yang menjadi penghalang terjadinya proses pembelajaran

3) Guru mencari solusi dari faktor-faktor penghambat untuk dijalankan pada siklus selanjutnya

\section{HASIL PENELITIAN DAN PEMBAHASAN}

\section{B. Hasil Penelitian}

1. Persiapan Sebelum Penelitian

Peneliti mengadakan beberapa persiapan yang diperlukan sebelum pelaksanaan penelitian.

\section{Pra Siklus}

Selama ini pembelajaran Penjumlahan Pecahan Penyebut Berbeda sebenarnya menyambung dan meluas dari tingkat pendidikan yang lebih rendah, namun begitu kondisi siswa dalam praktiknya belum mampu mengaplikasikan strategi pembelajaran yang berorientasi dalam kehidupan sehari-hari melalui penanaman nilai pada diri peserta didik. Serta masih terjadi komunikasi satu arah artinya peserta didik cenderung pasif dan kurang mempunyai pengalaman belajar dalam pembelajaran. Sehingga peserta didik kurang menyukai pelajaran Matematika dan menyebabkan hasil belajar rendah. Hal ini terbukti dengan rata-rata hasil belajar dan prosentase ketuntasan belajar peserta didik yaitu hasil dari evaluasi pra siklus peserta didik Kelas V pada tahun ajaran 2018/2019 semester I belum memenuhi Kriteria Ketuntasan Minimum (KKM).

Tabel 2 Hasil belajar dan Keaktifan peserta didik pra siklus

\begin{tabular}{|c|c|c|}
\hline $\begin{array}{c}\text { Rata-rata } \\
\text { Hasil belajar }\end{array}$ & $\begin{array}{c}\text { Ketuntasan } \\
\text { Belajar }\end{array}$ & $\begin{array}{c}\text { Keaktifan } \\
\text { peserta didik }\end{array}$ \\
\hline 63.33 & $58.33 \%$ & $56.50 \%$ \\
\hline
\end{tabular}


Berdasarkan data di atas dapat diperoleh nilai evaluasi pada tahap pra siklus adalah 63,33 dengan ketuntasan belajar 58,33\%. Dokumentasi ini diperoleh dari Guru Kelas V di SD Negeri 1 Kumai Hilir.

Berkaitan dengan keaktifan peserta didik, diperoleh berdasarkan wawancara dengan Guru Kelas V pada tanggal 16 Juli 2018, dengan prosentase keaktifan peserta didik adalah 56,5\%.

\section{Hasil Siklus I}

a. Perencanaan Tindakan

b. Pelaksanaan Tindakan

c. Observasi dengan mengamati terjadinya aktifitas belajar siswa, dengan ditandai menunjukkan perilaku teliti dalam menyelesaikan operasi hitung dalam bentuk pecahan.

Tabel 3 Perbandingan Prosentase Kemampuan pada Tahap Prasiklus dan Siklus I

\begin{tabular}{|l|l|l|}
\hline No. & Pelaksanaan Siklus & $\begin{array}{l}\text { Prosentase } \\
(\%)\end{array}$ \\
\hline 1 & Prasiklus & 56,5 \\
\hline 2 & Siklus 1 & 62,5 \\
\hline
\end{tabular}

Sebagaimana telah penulis paparkan pada sebelumnya bahwa pada penelitian ini, peneliti bertindak sebagai pelaksana kegiatan pembelajaran, Peneliti merasa belum siap untuk melaksanakan pembelajaran menggunakan penerapan media gambar dikarenakan guru belum pernah menerapkan metode- metode aktif tersebut sehingga takut apabila terjadi kesalahan atau tidak sesuai prosedur yang ditentukan. Oleh karena itu peneliti yang melaksanakan proses pembelajaran. Hal ini sah-sah saja baik peneliti maupun guru boleh menjadi pelaksana pembelajaran, asalkan menjalankan pembelajaran sesuai dengan rancangan yang dibuat dengan metode pembelajaran yang dibuat oleh peneliti.

Tabel 4 Prosentase Keaktifan Siswa Tahap Siklus I

\begin{tabular}{|c|l|l|}
\hline No. & Pelaksanaan Siklus & $\begin{array}{l}\text { Prosentase } \\
(\boldsymbol{\%})\end{array}$ \\
\hline 1 & Siklus I & 67,18 \\
\hline
\end{tabular}

Berkaitan dengan hasil tes akhir yang dilakukan di akhir pembelajaran pada siklus I didapat bahwa rata-rata hasil belajar pada tahap siklus I yaitu 69,71 (terlampir) yang berada di bawah standar yang ditentukan yaitu di bawah 70 dan dengan ketuntasan klasikal sebesar $66,66 \%$ dan ini masih dibawah indikator yang ditetapkan sebesar $75 \%$.

Tabel 5 Perbandingan Rata-rata Tes Akhir Pada Tahap Prasiklus dan siklus I

\begin{tabular}{|l|l|l|l|}
\hline No & $\begin{array}{l}\text { Pelaksanaan } \\
\text { Siklus }\end{array}$ & Rata-rata & $\begin{array}{l}\text { Prosentas } \\
\text { e }(\%)\end{array}$ \\
\hline 1 & Prasiklus & 63,33 & 58,33 \\
\hline 2 & Siklus I & 69,71 & 64,71 \\
\hline
\end{tabular}

d. Refleksi

Pelaksanaan tindakan dan pengamatan terhadap aktifitas guru dan peserta didik saat pembelajaran berlangsung akan diperoleh informasi tentang hasil observasi. Hasil observasi itu kemudian dianalisis dan didiskusikan bersama dengan guru sebagai bahan refleksi.

4. Siklus II

a. Perencanaan

Mengidentifikasi masalah berdasarkan refleksi siklus I dan alternative pemecahan masalahnya.

b. Pelaksanaan tindakan

Kegiatan yang dilaksanakan tahap ini yaitu Pengembangan rencana tindakan II dengan melaksanakan tindakan upaya lebih meningkatkan semangat belajar peserta didik dalam pembelajaran Penjumlahan Pecahan Penyebut Berbeda menggunakan alat peraga gambar yang telah direncanakan.

\section{c. Observasi \\ d. Refleksi}

1) Tes evaluasi pembelajaran Penjumlahan Pecahan Penyebut Berbeda menggunakan gambar di sekolah.

2) Menganalisis Hasil pengamatan untuk memperoleh gambaran bagaimana dampak dari tindakan yang dilakukan, hal apa saja yang perlu diperbaiki sehingga diperoleh hasil refleksi kegiatan yang telah dilakukan. 


\section{PEMBAHASAN}

Penelitian tindakan tahap prasiklus dilakukan untuk mengetahui hasil belajar peserta didik sebelum menggunakan media gambar. Tahap ini menggunakan nilai hasil belajar peserta didik sebelum penelitian dilaksanakan

Yang mana menunjukkan bahwa prosentase ketuntasan belajar pada materi penyembelihan adalah 58,33\% dengan nilai rata-rata 63,33. Data yang diperoleh tersebut dapat diambil kesimpulan bahwa hasil belajar peserta didik pada tahap prasiklus dalam pembelajaran matematika materi pokok Pembelajaran Penjumlahan Pecahan Penyebut Berbeda masih banyak terdapat nilai peserta didik dibawah rata-rata ketuntasan minimum yang telah diterapkan yaitu 70 (tujuh puluh).

Kemudian dilanjutkan dengan pembelajaran siklus I yang mana diketahui bahwa nilai rata-rata pada siklus I meningkat dibandingkan pada tahap prasiklus dari ratarata 63,33 menjadi 69,71 pada siklus I dengan prosentase sebesar $64,71 \%$. Sehingga dapat disimpulkan bahwa pada tahap siklus I ini hasil belajar peserta didik Kelas V SD Negeri 1 Kumai Hilir dalam pembelajaran menggunakan media gambar ada peningkatan. Tetapi masih harus dilaksanakan siklus ke 2 untuk mendapatkan nilai diatas kriteria ketuntasan minimal mata pelajaran Matematika di SD Negeri 1 Kumai Hilir.

Kemudian dilanjutkan lagi pada siklus kedua yang mana dapat diambil kesimpulan bahwa pada tahap siklus II hasil belajar peserta didik Kelas V SD Negeri 1 Kumai Hilir dalam pembelajaran menggunakan media gambar ada peningkatan drastis, dari semula jumlah ketuntasan $64,71 \%$ dengan nilai ratarata 69,71 pada siklus I menjadi $82,4 \%$ dengan nilai rata-rata 77,6 pada siklus II.

Yang akhirnya bisa kita lihat bahwa dalam pembelajaran pada siklus I menghasilkan rata-rata 69,71 , setelah di lakukan pembelajaran pada siklus II rata-rata

\section{PENUTUP}

\section{A. Simpulan}

naik menjadi 77,6. Jadi pembelajaran pada materi Pembelajaran Penjumlahan Pecahan Penyebut Berbeda dengan menggunakan gambar bisa meningkatkan prestasi belajar PAI siswa di SD Negeri 1 Kumai Hilir tahun pelajaran 2018/2019.

Dan untuk melanjutkan kebiasaan siswa dalam Pembelajaran Penjumlahan Pecahan Penyebut Berbeda baik dari urutan, maupun artinya, peneliti masih melanjutkan penggunaan media gambar karena sudah terbukti bisa meningkatkan prestasi belajar siswa.

Dengan demikian hipotesis tindakan dan indikator keberhasilan dapat dicapai sehingga tidak perlu dilakukan siklus berikutnya. Berdasarkan hasil tes praktik siklus II dengan rata-rata hasil belajar peserta didik 77,6 dan ketuntasan belajar $82,4 \%$, maka dapat disimpulkan dengan penerapan model pembelajaran dengan menggunakan media gambar dapat meningkatkan prestasi belajar peserta didik Kelas V SD Negeri 1 Kumai Hilir semester I tahun ajaran 2018/2019 pada materi pokok mempraktikkan Pembelajaran Penjumlahan Pecahan Penyebut Berbeda.

Berikut grafik peningkatan nilai rata-rata siklus I ke siklus II:

Grafik 1 peningkatan nilai rata-rata siklus I ke siklus II

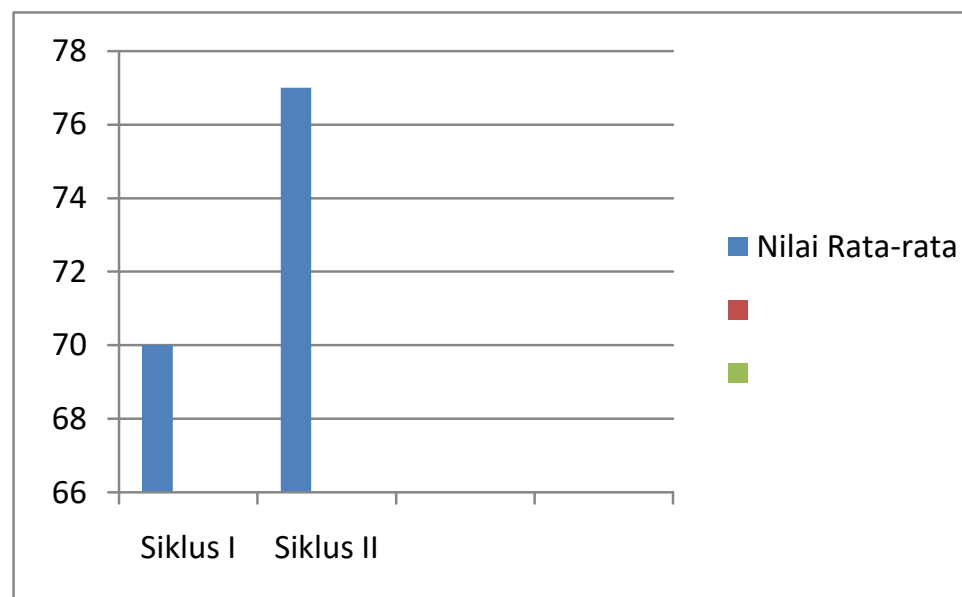

Berdasarkan penelitian tindakan kelas yang telah dilaksanakan, maka dapat disimpulkan:

1. Pembelajaran matematika yang dilakukan di SD Negeri 1 Kumai Hilir pada 
semester I tahun pelajaran 2018/2019 dilakukan dengan beberapa proses yang disusun dalam bentuk Rencana Pelaksanaan Pembelajaran (RPP) yang memuat langkahlangkah proses pembelajaran yaitu :(1) Kelas dibagi menjadi beberapa kelompok kecil (5 siswa) untuk memudahkan dalam pengawasan. (2) Guru menunjuk ketua dan sekretaris untuk mengkondisikan anggota kelompoknya masing-masing, yaitu mencatat para anggotanya . (3) Guru menjelaskan pelajaran menggunakan media gambar untuk lebih mudah diingat oleh siswa yang kemudian dipraktikkan oleh masing-masing kelompok dengan gambar masih dipasang di depan kelas.

(4) Masing-masing kelompok melaksanakan praktikkan tanpa gambar. (5) Guru mengamati pelaksanaan praktik siswa pada siklus I maupun siklus II. (6) Guru memastikan siswa melafalkan Pembelajaran Penjumlahan Pecahan Penyebut Berbeda dalam kondisi yang kondusif jadi siswa bisa fokus terhadap kegiatan pembelajaran. (7) Setelah selesai setiap kelompok ditanya dimana kesulitannya dalam Pembelajaran Penjumlahan Pecahan Penyebut Berbeda, kemudian ketua kelompok membimbing anggotanya yang masih kesulitan memecahkan masalah dimana yang masih dianggap sulit.

2. Pembelajaran matematika pada materi Pembelajaran Penjumlahan Pecahan Penyebut Berbeda dengan media gambar dapat meningkatkan prestasi belajar siswa Kelas V SD Negeri 1 Kumai Hilir Semester I tahun ajaran 2018/2019. Ini terbukti pada penelitian pra siklus rata-rata hasil belajar masih 63,33. Mengalami peningkatan pada siklus I menjadi 69,71 dan meningkat lagi pada penelitian tindakan siklus II sehingga dapat mencapai nilai diatas kriteria minimum 70 yaitu dengan nilai rata-rata 77,08 .

\section{B. Saran}

Mengingat pentingnya Pembelajaran Penjumlahan Pecahan Penyebut Berbeda c. Kepada semua pihak sekolah terutama para guru, sudah seharusnya meningkatkan kompetensi termasuk kompetensi professional untuk umat Islam lebih-lebih untuk anak-anak, maka guru harus lebih giat dalam melaksanakan pembelajaran tentang Pembelajaran Penjumlahan Pecahan Penyebut Berbeda untuk meningkatkan kesadaran akan pentingnya materi Pembelajaran Penjumlahan Pecahan Penyebut Berbeda pada peserta didik, peneliti mengharapkan beberapa hal yang berhubungan dengan masalah tersebut diatas sebagai berikut.

1. Kepada Guru Kelas

a. Hendaknya dalam proses belajar mengajar, guru harus benar-benar paham menyiapkan pembelajaran dengan sebaik mungkin, agar materi tersampaikan secara maksimal.

b. Dalam pembelajaran matematika guru harus mampu memilih model dan metode pembelajaran yang sesuai dengan materi yang akan disampaikan kepada peserta didik agar peserta didik merasa mudah dalam memahami materi.

c. Hendaknya pembelajaran dirancang sedemikian rupa dan memperkaya variasi mengajar. Hal ini untuk mengantisipasi kejenuhan yang dialami oleh peserta didik. Dan selalu memantau perkembangannya terutama dari perilaku, pemikiran dan pemahaman terhadap materi yang diajarkan.

d. Pelaksanaan pembelajaran dengan menggunakan gambar pada mata pelajaran Matematika materi Pembelajaran Penjumlahan Pecahan Penyebut Berbeda agar dapat dilakukan tidak hanya sampai pada selesainya penelitian ini saja, akan tetapi dilanjutkan dan dilaksanakan secara kontinu sebagai program untuk meningkatkan semangat dan mengurangi kejenuhan pada waktu melaksanakan pembelajaran.

2. Pihak sekolah

a. Hendaknya seluruh pihak sekolah mendukung dalam kegiatan pembelajaran yang berlangsung.

b. Memfasilitasi proses pembelajaran dengan melengkapi sarana dan prasarana yang dibutuhkan.

serta membekali diri dengan pengetahuan yang luas, karena sesungguhnya kompetensi yang dimiliki oleh guru sangat mempengaruhi 
keberhasilan proses pembelajaran, yang akhirnya akan dapat menghasilkan peserta didik yang berprestasi, berbudi pekerti luhur, dan berakhlaqul karimah yang mampu berdampak positif pada perkembangan dan kemajuan sekolah.

\section{DAFTAR PUSTAKA}

Armai Arief, Pengantar Ilmu dan Metodologi

Pendidikan Islam, Jakarta : Ciputat Pers, 2002

Azhar Arsyat, Media Pembelajaran, Jakarta :

PT. Grafindo Persada, 2003 Basyiruddin

Usman, Media Pembelajaran, Jakarta: Ciputat

Pers : 2002

dannyferdiansyah.blogspot.co.id/2013/11/mak

alah-tentang-kejujuran.html?m=1

Departemen Pendidikan dan Kebudayaan.

Kamus Besar Bahasa Indonesia. Jakarta. Balai

Pustaka.1991

homeworkapw.blogspot.co.id/2013/09/makala

h-sifat-terpuji-jujur_6860.html?m=1

Kementrian Pendidikan dan, Kebudayaan.

Pendidikan Agama Islam dan Budi Pekerti.

Jakarta. 2014

ukhuwahislah.blogspot.co.id/2013/10/makalah -jujur-da,lam-perkataan-dan.html?m=1

https://rahmatikhsan78.wordpress.com/2014/0

4/03/26/ Iqbal Hasan, Analisis Data Penelitian

Dengan Statistik, Jakarta: Bumi Aksara, 2004

Koentjaraningrat, Metode-metode Penelitian

Masyarakat, Jakarta: PT. Gramedia, 1991

M. Arifin, Filsafat Pendidikan Islam, Jakarta:

Bumi Aksara, 1996

Muhammad Ali, Strategi Penelitian

Pendidikan Statistik Bandung, Bumi Aksara,

1993
Muhibbin Syah, Psikologi Pendidikan Dengan

Pendekatan Baru, Bandung: Remaja

Rosdakarya Offset, 2002

Mukhtar, Desain Pembelajaran Pendidikan

Agama Islam, Jakarta : Mizaka Gazila, 2003

Nana Syaodih Sukmadinata, Metode

Penelitian Pendidikan, Bandung : Remaja

Rosda Karya, 2005

Nana Sudjana, Ibrohim, Penelitian dan Penilaian Pendidikan, Bandung: Sinar Baru, 1989

Pius A. Partanto dan M. Dahlan Al Barry,

Kamus Ilmiah Populer, Surabaya: Arloka, 1994

Saminanto, Ayo Praktik PTK (Penelitian

Tindakan Kelas), Semarang: RaSAIL, 2010

Suharsimi Arikunto, dkk, Penelitian Tindakan

Kelas, Jakarta: PT. Bumi Aksara, 2008

Teungku Muhammad Hasbi Ash Shidieqy, Al

Islam, Semarang: Pustaka Rizki Putra, 1998

W.J.S. Poerwodarminto, Kamus Umum

Bahasa Indonesia, Jakarta: Balai Pustaka, 1976.

Ramdhani, M. T., \& Istiqlaliyah, I. (20/8).

Manajemen Pembelajaran di MIS Hidayatul Insan Palangka Raya. Anterior Jurnal, I7(2), I25129. 